Acta Bot. Neerl. 34(1), February 1985, p. 49-58.

\title{
NEW RECORDS OF TERRICOLOUS \\ MICROLICHENS FROM SOUTHEAST GREENLAND
}

\author{
F. J. A. DANIËLS ${ }^{1}$, E. S. HANSEN ${ }^{2}$ and H. J. M. SIPMAN ${ }^{3}$ \\ ${ }^{1}$ Department of Plant Ecology, Lange Nieuwstraat 106, 3512 PN Utrecht, The Netherlands \\ ${ }^{2}$ Botanical Museum, University of Copenhagen, Gothersgade 130, 1123 Copenhagen, Denmark \\ ${ }^{3}$ Botanischer Garten und Botanisches Museum, Königin-Luise-Strasse 6-8, 1000 Berlin 33, \\ Germany
}

\begin{abstract}
SUMMARY
Twelve species of terricolous microlichens from the Angmagssalik District, Southeast Greenland, are reported: Caloplaca friesii, C. livida, Lecanora boligera, Lecidea oligotropha and Leciophysma arctophila, which are new to the lichen flora of Greenland, Rinodina conradi, which is new to the eastcoast, and Baeomyces roseus, B. rufus, Buellia geophila, B. punctata, Caloplaca tornoensis and Mycoblastus tornoensis, new to Southeast Greenland. In a discussion of the greenlandic distribution, unpublished records from the herbarium of Copenhagen $(\mathrm{C})$ are incorporated. Notes on the habitats are given and the pertinent phytosociological units indicated. Some morphological and anatomical characters are commented upon briefly.
\end{abstract}

\section{INTRODUCTION}

Until recently the lichen flora of Southeast Greenland was much less known than that of e.g. the westcoast (cf. LYNGE 1937, DaHL 1950, HANSEN 1978). In the last decades danish investigations are filling this gap in our knowledge, (HANSEN 1978, 1982), but, as usual, most attention has been paid so far to the macrolichens, and the microlichens remain much less known. A contribution to fill this gap for terrestrial microlichens has been made by dutch phytosociological expeditions to the Angmagssalik District in 1968 and 1969, the main results of which have been published by DaniëLS $(1975,1982)$ and De MolenaAR $(1974,1976)$. The microlichen finds were due to the research procedure followed. In an analysis of c. 600 sample plots not only vascular plants were treated, but bryophytes and lichens were included as much as possible, too. For this purpose many samples of the moss layer from the plots were brought into the laboratory. Examination by stereomicroscope revealed the presence on moss, litter and soil, of many inconspicuous microlichens. The most interesting finds of them are reported here.

\section{LOCALITIES}

The Angmagssalik District, situated on the southeast coast between c. $65^{\circ}$ and $67^{\circ} 20^{\prime} \mathrm{NL}$ (cf. fig. l), is the largest ice-free area of Southeast Greenland. It 


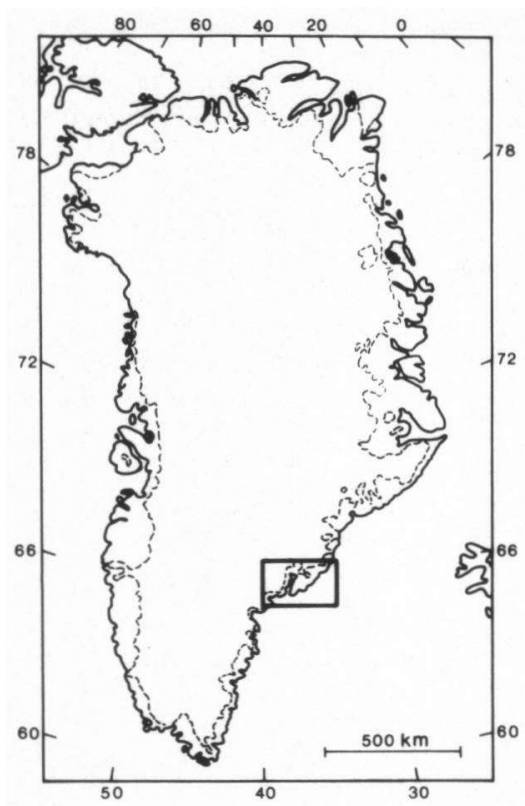

Fig. 1. Map of Greenland, showing the situation of the Angmagssalik District.

consists of a coastal part of moderate elevation, $\max .1000 \mathrm{~m}$, and an inland part with mountains up to $3000 \mathrm{~m}$, intersected by fjord systems. The climate at the coast is low-arctic oceanic (cf. BöcHER 1954, based on data from the town of Angmagssalik) and the main bedrock is precambrian gneiss (WRIGHT et al. 1973). The vegetation is restricted to favorable places, where low communities of shrubby or herbaceous plants occur. These are treated by DANiëLs (1975, 1982) and De MolenaAR $(1974,1976)$. For more information on the localities (cf. fig. 2) the reader is equally referred to these publications.

\section{SPECIES*}

\subsection{Baeomyces roseus Pers.}

Voucher specimen: Qingertivaq, Daniëls C-6.

This species is widely distributed in Greenland (HANSEN 1982). It grows usually in sheltered and moist places on clayish, more rarely humous, soil.

For Southeast Greenland the species is reported here for the first time. Apparently it is very rare in this region, since it has been found only once, on a crust of decomposed organic matter in a Rhododendro-Vaccinietum microphylli.

The specimen is sterile and was recognized by the presence of the characteristic globular, schizidia-like structures which are frequent in e.g. western European

* The voucher specimens are preserved in the herbarium of the Institute of Systematic Botany, Utrecht (U); the nomenclature of the syntaxa follows DANIËLS (1982). 


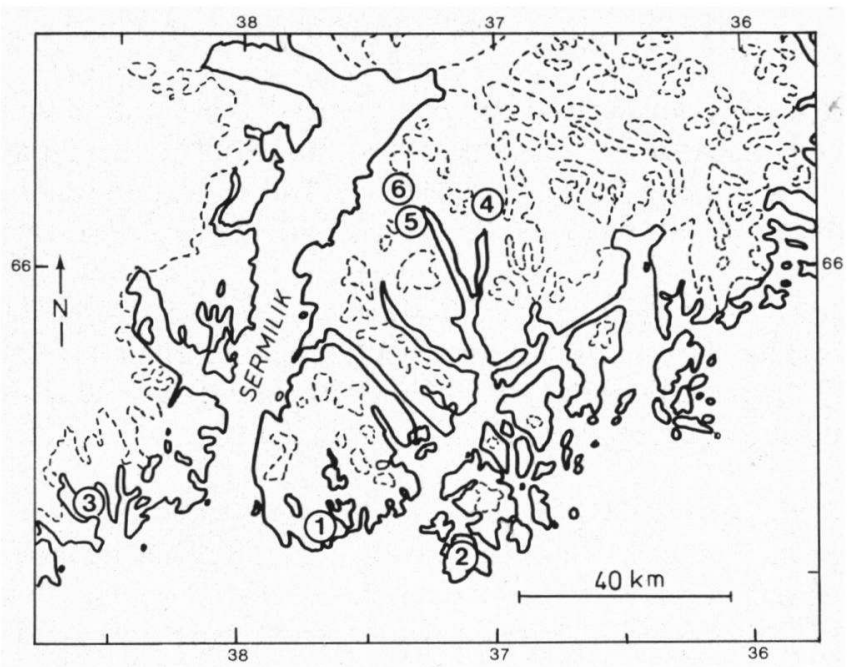

Fig. 2. Map of the Angmagssalik District, showing the collecting localities: 1. Surroundings of the town of Angmagssalik (Blomsterdalen, Elvbakker, Sermilikvejen and Sømandsfjeldet); 2. Kulusuk; 3. Nagtivit-Tasîlâlik; 4. Tasîlaq; 5. Qíngertivaq (incl. Cassiopefjeld and the foot of the Qaqarssuak massif); 6. Ilivnera.

representatives of the species (in herb. $U$ ), and by the presence of baeomycesic acid (demonstrated by TLC).

\subsection{Baeomyces rufus (Huds.) Rebent.}

Voucher specimen: Cassiopefjeld, Daniëls C-7.

Many collections of Baeomyces rufus are known from the area between Julianehåb (c. $60^{\circ} \mathrm{NL}$ ) and Nugssuaq (ca. $70^{\circ} \mathrm{NL}$ ) in West Greenland (unpublished, in herb. C), while the species has been observed more occasionally in Central East Greenland (LYNGE 1940). Generally it grows on fresh mineral soil (sand or clay) or soil rich in humus, but rarely over mosses. It prefers somewhat moist and sheltered places, such as snowbeds, Salix copses, dwarfshrub heaths and fens.

For Southeast Greenland Baeomyces rufus is reported here for the first time. It is presumably rare here, since it was collected only once. The find was in a Cassiopetum tetragonae.

The specimen is sterile and was recognized by the presence of schizidia and the substances norstictic and connorstictic acids (demonstrated by TLC).

\subsection{Buellia geophila (Flk. ex Sommerf.) Lynge}

Voucher specimen: Tasîlaq, Daniëls C-8.

According to HANSEN (1982) the distribution in Greenland is uncertain until the whole material of Buellia disciformis (Fr.) Mudd s.l. (including B. insignis) has been revised. So far it proved to be common in the northern parts of West 
and East Greenland (LYNGE 1937, 1940). Probably it becomes more rare towards the south.

There were no previous records from Southeast Greenland. In the Angmagssalik District it appears to be rare, since it was found only once among the many Buellia specimens present in the sample plots. This collection was from a dead plant cushion in Carici-Dryadetum integrifoliae on weakly acid soil at an altitude of $830 \mathrm{~m}$.

The specimen is identical with Buellia insignis (Naeg. ex Hepp) Th. Fr., var. insignis, except for the presence of three-septate spores. Since a specimen of the latter variety (Ilivnera, Daniëls C-9) contained some two-septate spores, the taxonomic value of spore septation might be low in this case.

\subsection{Buellia punctata (Hoffm.) Massal.}

Voucher specimens: Qingertivaq, Daniëls C-15; Sermilikvejen, Daniëls C-14.

Buellia punctata has a wide distribution in Greenland (cf. e.g. BöcHER 1954, ALSTRUP 1977). It has been reported from a great variety of substrates, such as bark of Sorbus, Salix, Betula and Alnus (ALSTRUP 1982), old wood, dead plant fragments, bones (BRANTH 1894), old excrements and siliceous rocks.

There are few previous records from the eastcoast of Greenland, all from the area between Scoresby Sund (c. $70^{\circ} \mathrm{NL}$ ) and Kejser Franz Joseph Fjord (c. $73^{\circ} \mathrm{NL}$ ). Now it turns out to be common in the Angmagssalik District, where it was found in a great variety of vegetation types e.g. the lichen-dominated Cladonio-Viscarietum alpinae (fig. 3), heath types like Cassiopetum tetragonae and Phyllodoco-Myrtillion, and Carici-Dryadetum. Its substrate was always dead moss or debris of vascular plants.

In the Angmagssalik District the present species is clearly distinct from the other common terricolous Buellia species, B. insignis, by its indistinct thallus, its small apothecia, and, notably, its smaller spores, which measure 12-15 $\times$ 6-7 $\mu$.

\subsection{Caloplaca friesii Magn.}

Voucher specimens: Elvbakker, Daniëls s.n., rec. nr. 68F66; Sømandsfjeldet, Daniëls C-27.

This species is reported here for the first time for Greenland. It has been observed three times in the coastal area of the Angmagssalik District, in Elvbakker, Sømandsfjeldet and Sermilikvejen, all at low altitude. As substrate were noted dead Peltigera remnants and dead twigs in litter in the Empetrum hermaphroditum-Vaccinium microphyllum community. It was often accompanied by Caloplaca tornoensis.

In the greenlandic specimens the apothecia are plane to slightly convex and range from 0.2 to $0.3 \mathrm{~mm}$ in width. The height of the hymenium measures $70-90$ $\mu$ and the spores measure 14-15 $\times 7 \mu$ and have a septum thickness of about one half of the spore length. Because the plants have an indistinct thallus and often only a few apothecia, Caloplaca friesii is an inconspicuous plant which may well have been overlooked in Greenland. The identification has been con- 


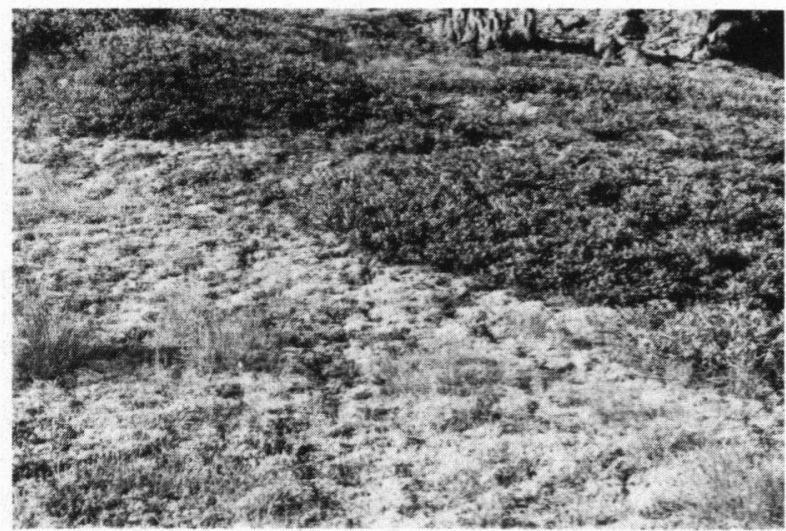

Fig. 3. A stand of the Cladonio-Viscarietum alpinae Daniëls 1982. This syntaxon appears to be rich in interesting microlichens, such as Buellia punctata, Caloplaca livida, C. tornoensis, Lecidea oligotropha and Rinodina conradi. Locality 1, Sermilikvejen, August 1969.

firmed by Prof. J. Poelt (Graz), who reports (in litt.) that he has observed the present species frequently during a recent visit to Greenland.

\subsection{Caloplaca livida (Hepp) Jatta}

Voucher specimens: Blomsterdalen, De Molenaar M68263B; Elvbakker, De Molenaar M6838A; Kulusuk, Daniëls C-21; Sermilikvejen, Daniëls C-20.

Like the preceding this species is new to Greenland. It has been collected rather frequently in the surroundings of the town of Angmagssalik, in chionophytic plant communities, e.g. Empetrum-Vaccinium heath and two types of lichendominated vegetation, Cladonio-Viscarietum and Polygono-Salicetum. Its substrate is compact litter.

When young the apothecia are nearly flat with a thin, concolorous margin, but usually they become soon convex and immarginate. Their diameter ranges from 0.3 to $0.6 \mathrm{~mm}$. The colour is usually brownish-orange, slightly more yellowish than in specimens from the Alps (in herb. U), but it varies from yellowish to dark brown. The height of the hymenium measures $50-60(-90) \mu$, and the spores 14-18 $\times(6-) 7-9 \mu$ with a septum thickness of about a quarter of the spore length. Although its thallus is indistinct, Caloplaca livida is not an inconspicuous plant, because it is crowded with bright-coloured apothecia (cf. fig. 4).

\subsection{Caloplaca tornoensis Magn.}

Voucher specimens: Blomsterdalen, Daniëls C-30; Cassiopefjeld, Daniëls C-33; Ilivnera, Daniëls C-34; Nagtivit, Daniëls C-32; Sømandsfjeldet, Daniëls C-29; Tasîlaq, Daniëls C-31.

Only one previous greenlandic report exists, from driftwood at the head of Antarctic Havn in Scoresby Land, Central East Greenland (HaNSEN 1982). 


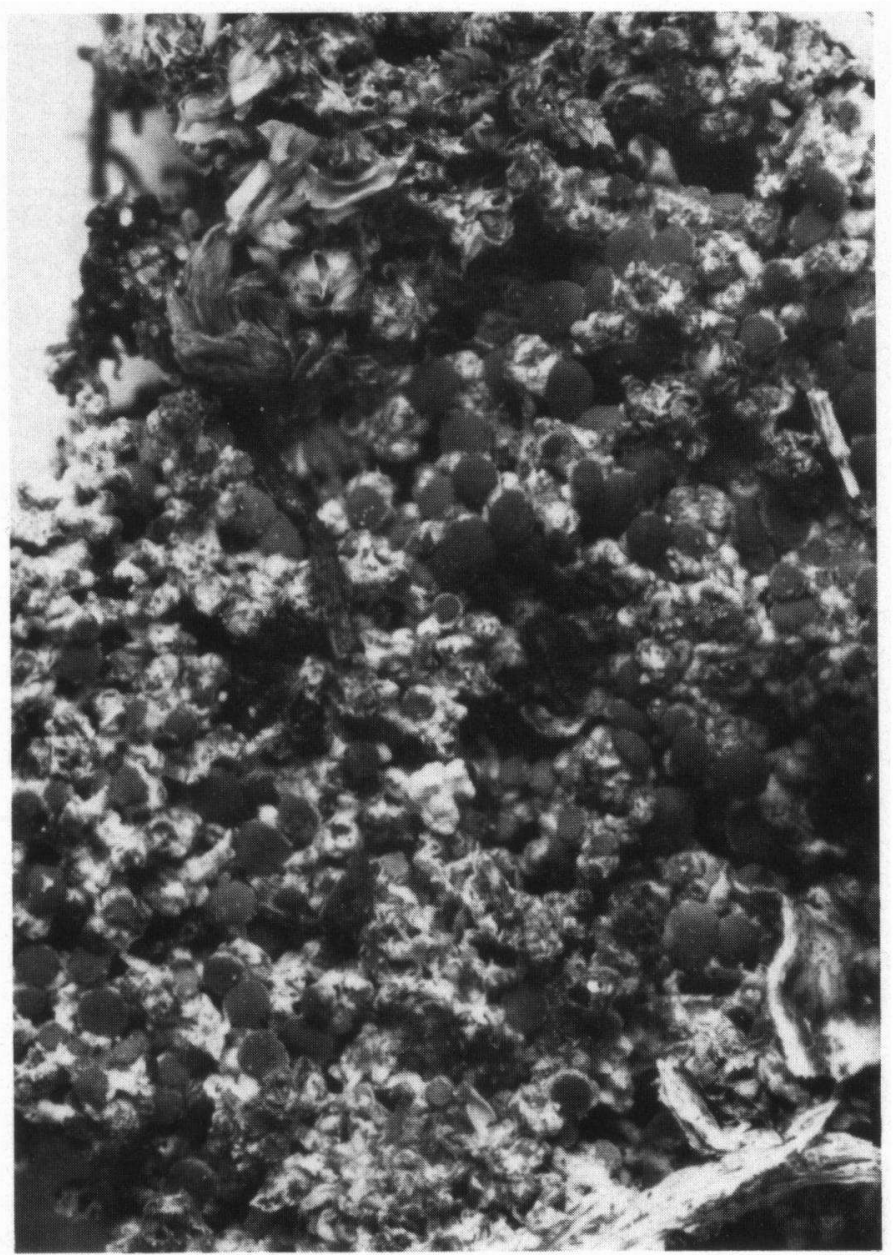

Fig. 4. A close-up of Caloplaca livida showing the apothecia. $\times 10$.

In the Angmagssalik District Caloplaca tornoensis appears to be not rare, because it was present in many coastal and one inland sample plot. Most of them belong to heath communities of the Loiseleurio-Vaccinietea, but some are of Cladonio-Viscarietum, Carici-Dryadetum or Pediculari-Vaccinietum microphylli, with strongly different ecology. As substrate dead plants and litter, preferably twigs, were observed.

The apothecia of the Southeast Greenlandic specimens are flat with a thick, prominent margin. They measure $0.3-0.5 \mathrm{~mm}$ in diameter. The colour of the disc is deep orange, the margin is concolorous or darker, brown to black. In this respect the Southeast Greenlandic specimens seem to differ from the European plants, which are stated to have always a black apothecial margin (MAG- 
NUSsON 1944, p. 17). The height of the hymenium measures $50-80 \mu$, the spores $12-16 \times 6-8 \mu$ with a septum thickness of about $\frac{1}{3}-\frac{1}{2}$ of the length of the spore.

\subsection{Lecanora boligera (Norm.) Hedlund}

Voucher specimens: Cassiopefjeld, Daniëls C-74; Qíngertivaq, Daniëls C-75.

These are the first records for Greenland. Specimens under this name in the herbarium C, leg. Gelting, from Central East Greenland, proved to be a mistake for Lecidea fuscescens Sommerf.

In the sample plots of the Angmagssalik District Lecanora boligera has been observed several times, and probably it is common here. As substrate were found exclusively dead twigs of dwarfshrubs, mostly Cassiope tetragona or Empetrum hermaphroditum, in communities of the achionophytic Loiseleurio-Diapension or in moss-rich dwarfshrub communities. Apparently the species is restricted to communities of the class Loiseleurio-Vaccinietea.

Lecanora boligera is characteristic by its spherical spores, which measure 6-7 $\mu$ in diameter in the Angmagssalik plants, and by the curious asci with thick tholi. The excipulum reacts negative with paraphenylene-diamine solution (in Lecidea fuscescens $\mathrm{P}+\mathrm{red}$ ). The plants are inconspicuous and consist usually of only a few apothecia with little or no thallus.

\subsection{Lecidea oligotropha Laund on}

Voucher specimens: Cassiopefjeld, Daniëls C-81; Kulusuk, Daniëls C-80.

Lecidea oligotropha has not been recorded for Greenland before. It occurred in several sample plots in the Angmagssalik District, mostly in coastal stations, and usually on litter, in various vegetation types, e.g. Cladonio-Viscarietum, Salix callicarpaea-Cetraria nivalis community and Loiseleurio-Vaccinietea, which have in common being rich in fruticose lichens.

As usual, the species was mostly sterile, and recognizable by the rather coarse thallus granules. In this respect it resembles Lecidea uliginosa (Schrad.) Ach., which has equally been found in the sample plots of the Angmagssalik District. The main difference between both species is in the size of the thallus granules: in Lecidea oligotropha they measure 100-300 $\mu$, in L. uliginosa less then $50 \mu$ (Laundon 1961, p. 165). Apothecia were present in a single collection, Daniëls C-80. They resemble those of Lecidea uliginosa closely. The height of the hymenium measured 45-90 $\mu$, the spores 12-14 $\times$ 4-7 $\mu$. Coppins (Edinburgh) confirmed the identification.

\subsection{Leciophysma arctophila (Th. Fr.) Sant.}

syn.: Parmeliella arctophila (Th. Fr.) Malme

Voucher specimen: Sømandsfjeldet, Daniëls C-130.

No previous report for Greenland exists in the literature. There are a few unpublished collections in $\mathbf{C}$, however, made by Gelting on Disko. These are from mosses in e.g. subsaline meadows and around lagoons. 
In the Angmagssalik District the species was found once. Thus it can be considered as rare. The collection is from a dead crust of Drepanocladus uncinatus in Empetrum-Vaccinium heath.

JöRGENSEN (1978) has discussed the taxonomic status of the species, and was of the opinion that it should be taken out of the genus Parmeliella and transferred to the Collemataceae or Placynthiaceae. Subsequently SANTESSON (1984) sanctioned its position in Leciophysma.

\subsection{Mycoblastus tornoensis (Nyl.) Anderson} syn.: Lecidea tornoensis Nyl.

Voucher specimens: Cassiopefjeld, Daniëls C-85; Qíngertivaq, Daniëls C-86; Sermilikvejen, Daniëls C-84.

This inconspicuous species is widely distributed in Greenland and apparently common along the westcoast (LYNGE 1937). In $C$ there are many collections from Central East Greenland. From Northeast Greenland there is only a single report, from Landingsdalen (LYNGE 1940), however. Its usual substrate is moss or dead plant fragments (ALSTRUP 1982), but also bark of trees or shrubs like Betula pubescens and Salix glauca.

In the Angmagssalik District the species has now been found frequently, mostly on small twigs in the litter layer of dwarfshrub communities.

Mycoblastus tornoensis is well characterised by its thickwalled spores and small, glossy, convex apothecia of a darkbrown colour with a purplish tinge. The following measurements have been made: apothecia c. $0.5 \mathrm{~mm}$ in diameter; spores 18-22 $\times 9-11 \mu$. Most plants bear only a few apothecia. The inclusion in the genus Mycoblastus has been questioned (e.g. HAwKsworTH et al. 1980), and no doubt the species is only remotely related with $M$ ycoblastus species like $M$. sanguinarius. But there seems to be less relationship with the type species of the genus Lecidea and its allies.

\subsection{Rinodina conradi Körb.}

Voucher specimens: Blomsterdalen, Daniëls C-146; Elvbakker, De Molenaar M6838D; Qingertivaq, Daniëls C-145.

Only a single record of Rinodina conradi for Greenland exists in the literature, viz. from Juniperus near Tasermiut, South Greenland (BRANTH 1892). In C a second collection is present, from Fortunebay on Disko, collected by Gelting and identified by A. H. Magnusson. It was growing on dead lichens.

In the Angmagssalik District Rinodina conradi has now been found in three stations, on litter in Cladonio-Viscarietum and Phyllodoco-Salicetum callicarpaeae. The stations are rich in lichens and have a southern aspect.

The height of the hymenium of the Southeast Greenlandic specimens varies from 70 to $80 \mu$, the spores measure 20-27 $\times 8-10 \mu$. Rinodina conradi resembles $\boldsymbol{R}$. olivaceobrunnea Dodge \& Baker (syn.: $R$. archaeoides Magn.) closely, and can be separated from it only after examination of the spores. Moreover both species seem to have about the same habitat requirements in the Angmagssalik District, but $R$. conradi is apparently much less common than $R$. olivaceobrun- 
nea, which has been found in over 40 sample plots.

\section{ACKNOWLEDGEMENTS}

We thank B. Coppins, Edinburgh, for the verification of our determination of Lecidea oligotropha, and J. Poelt, Graz, for the verification of the Caloplaca species. The photograph of CCaloplaca livida was made by Flemming Sarup, who used a Willd Photomacroscope M 400, granted to Finn Rasmussen by the Danish Natural Science Research Council.

\section{REFERENCES}

ALSTRUP, V. (1977): Cryptogams on imported timber in West Greenland. Lichenologist 9: 113-117. - (1982): The epiphytic lichens of Greenland. Bryologist 85: 64-73.

BöCHER, T. W. (1954): Oceanic and continental vegetational complexes in Southwest Greenland. Meddr. Granland 148: 1-336.

BraNTH, J. D. (1892): Tillaeg til Grønlands Lichen-Flora. Meddr. Gronland 3: 751-762.

- (1894): Lichener fra Scoresby Sund og Hold with Hope. Meddr. Gronland 18: 83-103.

DAHL, E. (1950): Studies in the macrolichen flora of South West Greenland. Meddr. Gronland 150: $1-176$.

DANIËLS, F. J. A. (1975): Vegetation of the Angmagssalik District, Southeast Greenland III. Meddr. Grenland 198: 1-32.

- (1982): Vegetation of the Angmagssalik District, Southeast Greenland IV. Meddr. Gronland. Bioscience 10: 1-78.

HANSEN, E. S. (1978): Notes on the occurrence and distribution of lichens in Southeast Greenland. Meddr. Gronland 204, 4: 1-71.

- (1982): Lichens from Central East Greenland. Meddr. Gronland. Bioscience 9: 1-33.

Hawksworth, D. L., P. W. JAMEs \& B. J. Coppins (1980): Checklist of British lichen-forming, lichenicolous and allied fungi. Lichenologist 12: 1-115.

JöRgEnsEn, P. M. (1978): The lichen family Pannariaceae in Europe. Opera Botanica 45: 1-123.

LAUNDON, J. R. (1961): Lichens new to the British Flora 2. Lichenologist 1: 158-168.

LYNGE, B. (1937): Lichens from West Greenland, collected chiefly by Th. M. Fries. Meddr. Gronland 118: $1-225$.

- (1940): Lichens from Northeast Greenland II. Microlichens. Skr. Svalb. og Ishavet 81: 1-143.

Magnusson, A. H. (1944): Studies in the Ferruginea-Group of the genus Caloplaca. Göteborgs K. Vetensk. o. Vitterh. Samh. Handl., ser. 6B, 3, 1: 1-71.

MolenaAR, J. G. DE (1974): Vegetation of the Angmagssalik District, Southeast Greenland I. Meddr. Gronland 198, 1: 1-79.

- (1976): Vegetation of the Angmagssalik District, Southeast Greenland II. Meddr. Grenland 198, 2: $1-265$.

SANTEsson, R. (1984): The Lichens of Sweden and Norway. Swedish Museum of Natural History, Stockholm, \& Uppsala.

Wright, A. E., J. TARney, K. F. Palmer, B. S. P. Moorlock \& A. C. Skinner (1973): The geology of the Angmagssalik Area, East Greenland, and possible relationships with the Lewisian of Scotland. In: The Early Precambrian of Scotland and related rocks of Greenland (R. G. PARK \& J. TARNEY, eds.). University of Keel, New Castle: 157-177. 